\title{
AMELIORATION OF LEAD INDUCED CHANGES IN THE TESTES OF SPRAGUE-DAWLEY RATS, BY METHANOL EXTRACT OF TELFARIA OCCIDENTALIS
}

${ }^{1}$ FALANA BA, ${ }^{1}$ ADEKEYE WM, ${ }^{1}$ ADELEKE SO

\author{
Department of Anatomy, Faculty of Basic Medical Sciences College of Health Sciences Osun State \\ University, PMB 4494, Osogbo, Osun State, Nigeria.
}

\begin{abstract}
*Correspondence to Falana Benedict. Correspondence address: Department of Anatomy, College of health Sciences, Osun State University, Osogbo, Osun State. Email address:

benedict.falana@uniosun.edu.ng; Tel: +2348067033706
\end{abstract}

\begin{abstract}
The prevalence of infertility due to industrial, environmental and pharmaceutical toxins induced by lead in Nigeria and in developing countries is alarming. The use of medicinal plants as fertility enhancer in human is now in the increase because of the shifting of attention from synthetic drugs to natural plants. Thus, this study investigated the effect of methanolic extract of Telfairia occidentalis on $(\mathrm{Pb})$ lead-induced testicular damage in adult male Sprague-Dawley rats. Twenty-four (24) Sprague dawley (SD) rats with average weight of $130 \mathrm{~g}$ were randomly divided into four groups of six animals each. Group A served as the control group administered normal saline. Group B received 75mg/kg body weight of lead $(\mathrm{Pb})$ as Lead nitrate only. Group $\mathrm{C}$ received $75 \mathrm{mg} / \mathrm{kg}$ body weight of lead $(\mathrm{Pb})$ and $300 \mathrm{mg} / \mathrm{kg}$ body weight of methanolic extract of Telfairia Occidentalis, while Group D receive $300 \mathrm{mg} / \mathrm{kg}$ body weight of methanolic extract of Telfairia Occidentalis only. Administration was via oral canula and the animals were sacrificed on 15th day. Blood samples were obtained via the left ocular sinus for haematological and hormonal studies while the testes and epididymis were removed and fixed in Bouin's fluid for histological analysis. Administration of Telfairia Occidentalis improves testicular testosterone and PCV levels and also restored the histoarchitecture of the testes in SD rats. It is therefore suggested that the antioxidant potential of this wonder plant may have beneficial effects in treating male factor infertility as shown in this present study.
\end{abstract}

Keywords: Male infertility, Telfairia occidentalis, Lead (Pb), Antioxidants.

\section{INTRODUCTION}

Infertility is a worldwide health problem and it is one of the most stressful conditions amongst married couples (Oyewopo et al., 2018). Robertson in the year 2015 describe infertility has failure to conceive, despite having engaged in regular and unprotected intercourse for a year. The World Health Organization (WHO, 1991) estimates that 8$12 \%$ of couples' worldwide experience some forms of infertility during their reproductive lives, thus affecting 50-80 million couples, with 20-30 million in Africa.

A considerable amount of research has been directed toward the study of plants with the goal of providing new and improved treatment for infertility. Most of the plants widely studied are consumed by man. One such plant is a nutritious vegetable, Telfairia occidentalis.
Telfairia occidentalis is a member of the Cucurbitaceae family which consists of two other species (Akoroda, 1990). It is a perennial, drought tolerant plant (Nwanna et al., 2008) widely grown and consumed as vegetable in the West Africa. It is widely known with common names such as fluted pumpkin, fluted gourd and "Ugu" as it is called in the Nigerian Igbo language (Akoroda, 1990). The plant consists of leaves and an edible seed. It is a rich source of protein containing as much as $37 \%$ protein per $100 \mathrm{~g}$ of Telfairia occidentalis leaf meal. It contains fats, vitamins (e.g. riboflavin, Vitamin C, and nicotinamide) and minerals such as calcium and magnesium, polyphenols, and flavonoids (Okoli, et al., 1983). In addition, it contains marked amounts of tannins, saponins, and alkaloids (Aiyelaagbe et al., 2002). A significant amount of literature 
exists on the medicinal effects of Telfairia occidentalis in various tissues and organs of treated animal models. For instance, Telfairia occidentalis is known to possess antidiabetic, antibacterial and anti-inflammatory properties (Emebiri et al., 1990). Also attributed to Telfairia occidentalis is its effectiveness in the treatment of hypercholesterolemia (Nwufo et al., 1994) and amelioration of the effects of quinine induced testicular damage (Emebiri et al., 1990) It has also been noted that $\mathrm{T}$. occidentalis causes significant increases in total protein and total bilirubin levels, as well as albumin, globulin and conjugated bilirubin although it has a hepatoprotective effect on the liver even at high doses of administration in Wistar rats (Badifu et al., 1993). Hematological studies conducted have shown that it increases packed cell volume, hemoglobin concentration and total white blood cell count (Giami et al., 2003). Akang et al., 2015 reported that T. occidentalis causes significant increases of seminiferous epithelium in rats' testes.

\section{MATERIALS AND METHODS}

Telfairia Occidentalis leaves were obtained from a local market in Oke-bale, Osogbo, Nigeria. The leaves were then identified and authenticated at Botany Department, Osun State University, Osogbo, after which the leaves of the plant were cut into pieces, air dried and then pulverized into powdered form using an electric blender.

Two hundred grams $(200 \mathrm{~g})$ of the powdered leaf were macerated in methanol for $72 \mathrm{~h}$, and occasionally stirred. The mixture was then filtered with a mesh of $\mathbf{2 0 0}$ micrometer. After filtration, it was transferred to a beaker to evaporate completely in a water bath at 40 degree Celsius. The process was repeated for 3 days to give $32.54 \mathrm{~g}$ of brown residue. The methanolic extract used in the study was prepared by dissolving $25 \mathrm{~g}$ of the residue in $250 \mathrm{ml}$ of distill water. The dosage of methanolic extract of Telfairia Occidentalis used in the study was $300 \mathrm{mg} / \mathrm{kg}$ of body weight.

Animals used for the experiment weighed between $120-140 \mathrm{~g}$, the animals were randomly divided into four groups of six animals each. Group A which serve as the control group received normal saline. Group $B$ receive $75 \mathrm{mg} / \mathrm{kg}$ body weight of lead (Pb). Group $\mathrm{C}$ receive $75 \mathrm{mg} / \mathrm{kg}$ body wight of lead $(\mathrm{Pb})$ and $300 \mathrm{mg} / \mathrm{kg}$ body weight of methanolic extract of Telfairia Occidentalis while Group D receive $300 \mathrm{mg} / \mathrm{kg}$ body weight of methanolic extract of Telfairia Occidentalis only. The extract was administered orally and the administration lasted for 14 days after which the experimental animals were then sacrificed. The testes dissected from the rats were placed in sample bottles containing Bouin's fluid for further tissue processing and histological analysis. Blood was also obtained via ocular puncture for haematological and hormonal studies.

The testes of all the rats were fixed in Bouin's fluid, dehydrated stepwise in graded ethanol, cleared in xylene and then embedded in paraffin wax. A section of $5 \mu \mathrm{m}$ thick paraffin section of each testicular tissue was stained with hematoxylin and eosin, followed by examination under a light microscope at $\times 100$ and $\times 200$ magnification and micrographs taken.

Blood samples of about $1.5 \mathrm{ml}$ were obtained from the rats by ocular puncture using capillary tube and each blood from the group were spun at 2500rmp for 10 minutes in a desktop centrifuge, to obtain the serum from the blood and stored at -20 degree Celsius for subsequent hormone assay. The serum testicular testosterone levels were measured using enzyme linked immunosorbent assay technique (ELISA kit with product code 3725300 produced by Monobind Inc. Lake Forest CA. 92630 USA) was used. The optical density was read using a spectrophometer made by BioTek and the spectrophometer was sensitive at wavelength between 492-550 $\mathrm{nm}$.

The hematocrit or packed cell volume (PCV) determines the percentage of red blood cells (RBCs) in the whole blood. hematocrit determinations was manually performed by the microhematocrit method. 
White blood cells are a heterogeneous group of nucleated cells that play a major role in phagocytosis and immunity and therefore in defence against infection. The white blood cells was counted manually in specially designed chambers called Neubauer chambers. The four large squares placed at the corners in the Neubauer chambers were used for the white blood cell count. The samples were diluted to a suitable concentration. $20 \mathrm{ml}$ of the cell mixture (dilution) was then carefully draw up with a pipette and the tip of the pipette was placed against the edge of the cover glass and the liquid was slowly expelled until the counting chamber was full. The Neubauer chamber was placed on the microscope stage using the 10x objective, focused both onto the grid pattern and the total number of cells found in four (4) large corner squares were then counted and recorded. The total number of cells per microliter of sample was calculated from the number of cell counted and area counted. This is because the ruled areas of the chamber contain an exact volume of diluted sample. Since only a small volume of diluted sample is counted, a general formula must be used to convert the count into the number of cells/microliter. The formula is as shown below:

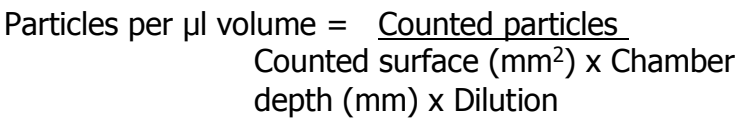

Results obtained from the Hormonal and Hematological analysis were statistically analyzed using Graphpad Prism version 5.0. The results were presented as Mean \pm SEM (Standard Error of Mean) and student t-Test to see the correlation between the control and the treated groups. Significant level at $p$-value < 0.05 .

\section{RESULTS}

\section{Hormonal Analysis}

Statistical analysis of the result from Figure 1 shown the mean testosterone level of Group D $(300 \mathrm{mg} / \mathrm{kg}$ per body weight of methanolic extract of Telfairia occidentalis) was significantly higher $(P<0.0001)$ when compared with the control group A. Group B, which receive $75 \mathrm{mg} / \mathrm{kg}$ per body weight of lead has a significant lower $(P<0.001)$ level of testosterone when compared with the control group. Group C, which received both $75 \mathrm{mg} / \mathrm{kg}$ per body weight of lead and $300 \mathrm{mg} / \mathrm{kg}$ per body weight of methanolic extract of Telfairia occidentalis extract has a slight significant increase $(P<0.05)$ in testosterone level when compared with control Group A.

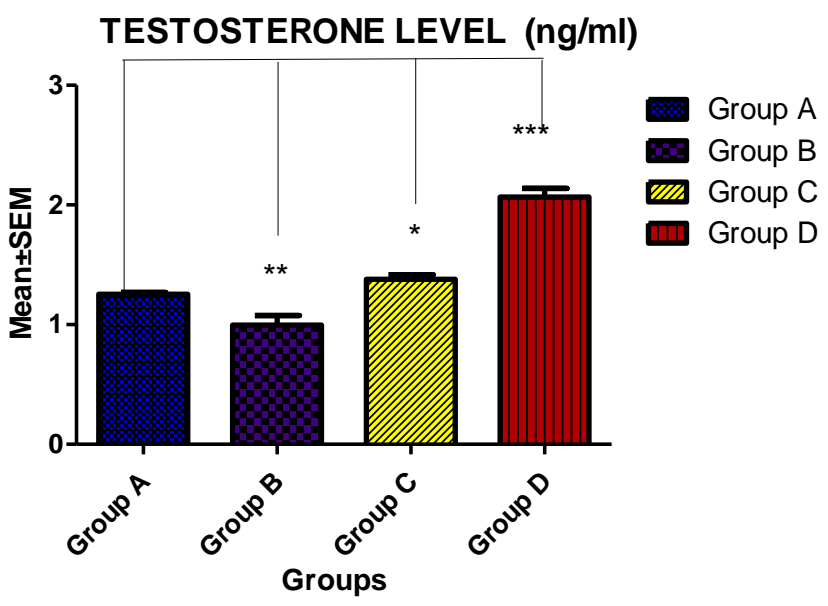

Figure 1: Shown comparison between the Control Group $A$ and treated Groups $(B, C, D)$ testosterone level after administration of Lead and Methanolic extract of Telfairia occidentalis. $(* P<0.05, * * P<0.01, * * * p<0.001)$. 


\section{Hematological Analysis}

Result from figure 2 depicts the mean value of Packed Cell Volume (PCV \%) in Group D which receive $300 \mathrm{mg} / \mathrm{kg}$ per body weight of Methanolic extract of Telfairia occidentalis was significantly higher $(P<0.01)$ while that of Group B which only receive $75 \mathrm{mg} / \mathrm{kg}$ per body weight of lead was significantly lower $(P<0.01)$ when compared with Control Group A. Group C which received $75 \mathrm{mg} / \mathrm{kg}$ per body weight of lead and $300 \mathrm{mg} / \mathrm{kg}$ per body weight of methanolic extract of Telfairia occidentalis PCV mean value was slightly increased $(P<0.05)$ when compared with Control Group
Furthermore, White blood cell (WBC cells $/ \mathrm{mm}^{3}$ ) levels, as shown in figure 3, revealed that Group B which receive $75 \mathrm{mg} / \mathrm{kg}$ per body weight of lead and Group $C$ which receive $75 \mathrm{mg} / \mathrm{kg}$ per body weight of lead and $300 \mathrm{mg} / \mathrm{kg}$ per body of methanolic extract of Telfairia occidentalis has a slight significant increase $(P<0.05)$ in mean value of WBC while Group D which receive $300 \mathrm{mg} / \mathrm{kg}$ per body weight methanolic extract of Telfairia occidentalis has a significant lower value $(P<0.01)$ of WBC when compared with control Group A rats.

A.

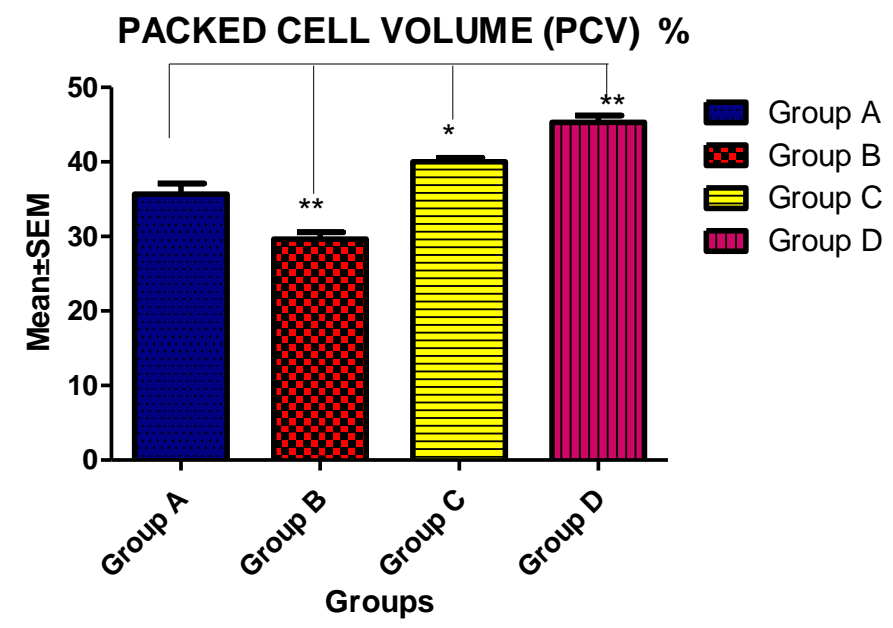

Figure 2: Shown comparison between the control and treated groups $(B, C, D)$ Packed Cell Volume (\%) after administration of Lead and Methanolic extract of Telfairia Occidentalis. $(* P<0.05, * * P<0.01)$.

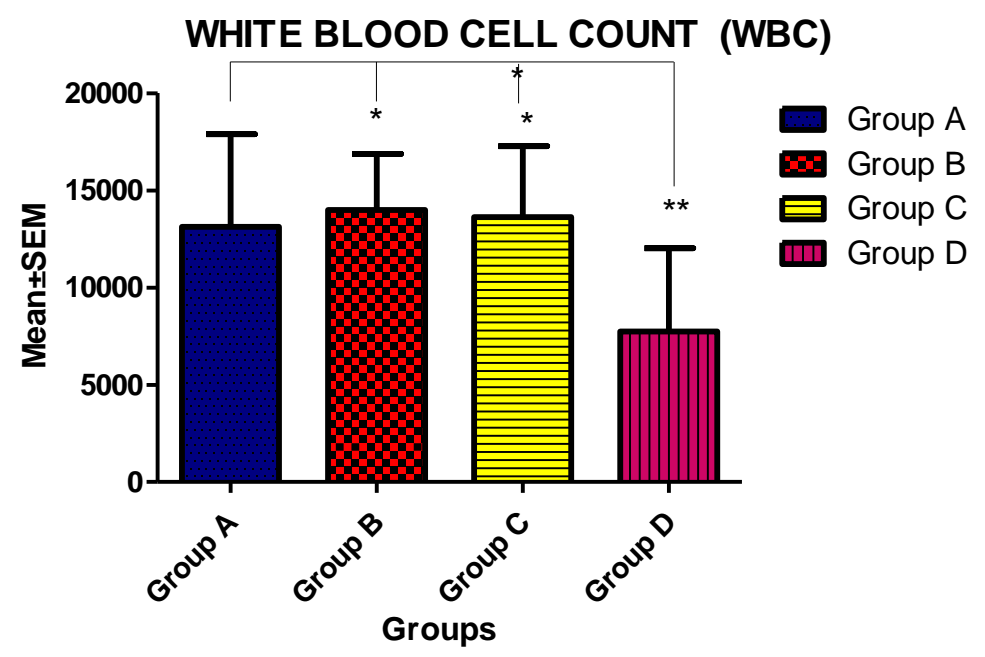

Figure 3: Shown comparison between the control and treated groups $(B, C, D)$ white blood cell count $\left(\right.$ cells $\left./ \mathrm{mm}^{3}\right) .\left({ }^{*} P<0.05\right.$, $* * P<0.01)$. 


\section{Histological Findings}

The testes and epidydymis from each experimental group were histologically analysed using Masson's Trichome Stains.

Figure 4 and 5 shown the testicular histoarchitecture of rats in experimental Groups A - D at x40 and x100 magnification respectively. Control (Group A) showing normal and concentric seminiferous tubules (ST) with intact basal membrane and lumen condensed with mature sperm cells. Together with, the interstitial spaces (IS) which are well delineated and there are no signs of testicular degeneration. Group B $(75 \mathrm{mg} / \mathrm{kg}$ per body weight of lead) however showed few seminiferous tubules with little or no mature spermatozoa (spermatogenic arrest) in the lumen as well as a thin basal lamina with derangement. Group $C(75 \mathrm{mg} / \mathrm{kg}$ per body weight of lead and $300 \mathrm{mg} / \mathrm{kg}$ body weight of methanolic extract of Telfairia Occidentalis) showed normal and concentric seminiferous tubules (ST) with intact basal membrane and lumen containing mature sperm cells. Together with, the interstitial spaces (IS) which are well delineated and defined. Group D (300 mg/kg body weight of methanolic extract of Telfairia occidentalis) showed normal and concentric seminiferous tubules (ST) with intact basal
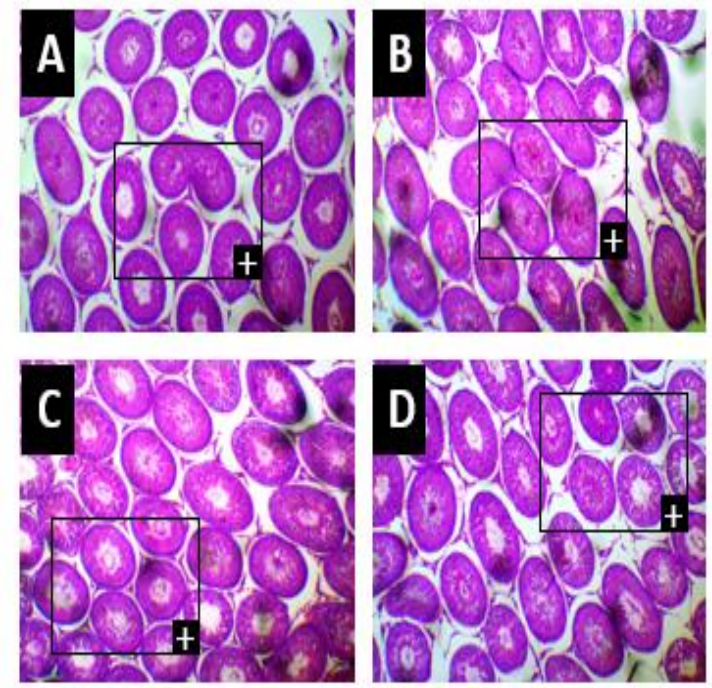

membrane and lumen condensed with mature sperm cells. Together with, the interstitial spaces (IS) which are well delineated and there are no signs of testicular degeneration and atrophy.

Moreover, Figure 6 and 7 shown the epididymal histoarchitecture of rats in experimental Groups A - D at x40 and x100 magnification respectively. Control (Group A) showing the germinal epithelium (GE) that is generally devoid of disturbance, with consistency and abundance of spermatozoa (S) in the lumina ( $L$ ) of the epididymal duct. Group $B(75 \mathrm{mg} / \mathrm{kg}$ per body weight of lead) however showed depletion of lumina content as well as extravasations of germinal epithelium into the interstitium and within the lumen. Group C $(75 \mathrm{mg} / \mathrm{kg}$ per body weight of lead and $300 \mathrm{mg} / \mathrm{kg}$ body weight of methanolic extract of Telfairia occidentalis) showed germinal epithelium (GE) that is devoid of disturbance, with consistency and presence of spermatozoa $(S)$ in the lumina $(L)$ of the epididymal duct. Group D $(300 \mathrm{mg} / \mathrm{kg}$ body weight of methanolic extract of Telfairia Occidentalis) showed germinal epithelium (GE) that is generally devoid of disturbance, with consistency and abundance of spermatozoa (S) in the lumina $(\mathrm{L})$ of the epididymal duct.
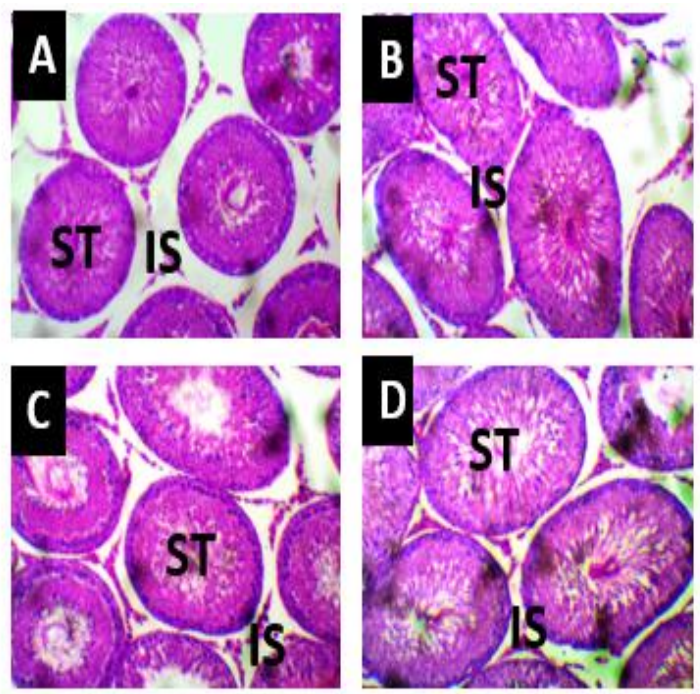

Figure 5 ts in experimental groups A - D ( x40 and x100
F Figure 4 Photomicrograph shown the testicular histoarc M\&T) . Seminiferous tubules (ST); Interstitial spaces (IS). 


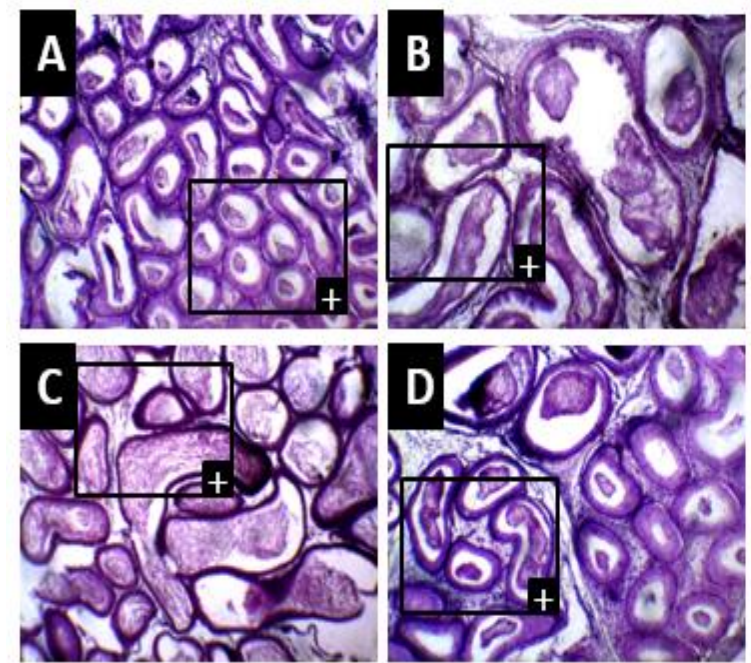

Figure 6

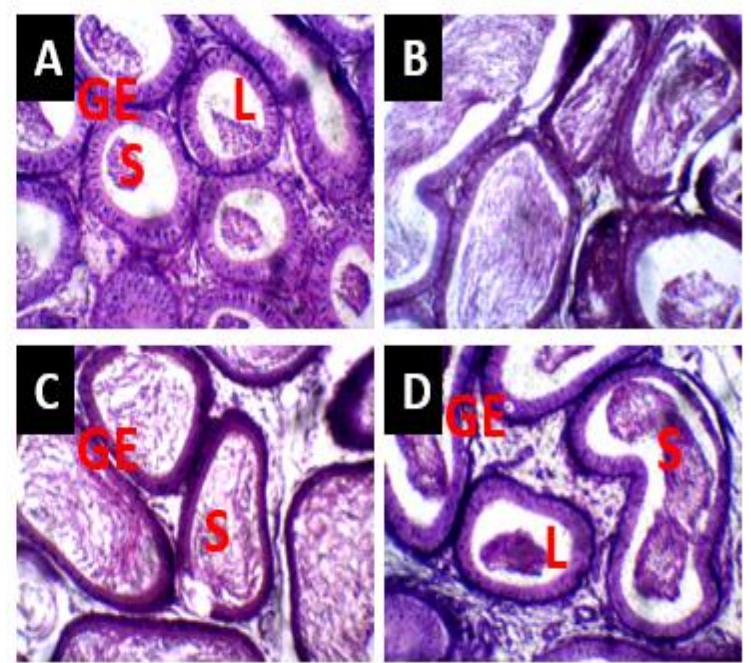

Figure 7

Figure 6,7: Representative photomicrograph shown the epididymal histoarchitecture of rats in experimental groups A - D (x40 and x100 M\&T). Germinal epithelium (GE); Spermatozoa (S); Lumen (L).

\section{DISCUSSION}

In this study, it was observed that administration of lead $(\mathrm{Pb})$ as lead nitrate to the experimental rats induced testicular damage in male Sprague Dawley rats. This is in agreement with the study of Falana et al., (2013) which reported reversal of degeneration of spermatocytes induced by $\mathrm{Pb}$ treatment in rats. In their study this degeneration was reversed by selenium and zinc co administration. The administration of methanolic extract of Telfairia occidentalis was able to ameliorate the damaging effect of the lead $(\mathrm{Pb})$ due to its high anti-oxidant property which helps to protect the testicular cells from the damaging effect caused by oxidative stress. The investigations which was carried out after 14 days of administration, showed the effect of lead $(\mathrm{Pb})$ and Telfairia occidentalis on the following: Testicular testosterone levels, haematological parameters, libido and fertility.

Administration of lead $(\mathrm{Pb})$ in Group B shows significant decrease in serum testosterone level compared to all other experimental groups (Figure 1). In another study, lead acetate suppressed serum testosterone, FSH and LH levels along with testicular spermatogenesis, showing that lead acts at all levels of reproduction. Administration of $0.1 \%$ lead acetate in male wistar rats by Shaban et al., 2010 again suppressed serum testosterone levels and blood lead levels exceeded by
$22 \mu \mathrm{g} / \mathrm{dl}$ again confirming our results. Regarding different durations of treatment, data of another study verified that increased duration of exposure to lead acetate after 14 days did not further suppress serum testosterone levels or spermatogenesis (Hassan et al., 2013).

Administration of lead $(\mathrm{Pb})$ and methanolic extract of Telfairia occidentalis to experimental rats in Group C shows improved level of testosterone compared to Group which only receive lead $(\mathrm{Pb})$. The improved testosterone level in Group $C$ can be attributed to the antioxidant property of methanol extract Telfairia occidentalia.

Administration of lead $(\mathrm{Pb})$ only in Group B decreases Packed Cell Volume (PCV) of the experimental rats. This is in accordance with the study conducted by (Mohammadhosein, 2003) in which there is reduction in levels of PCV in the group where lead (Pb) acetate was administered resulting in microcytic hypochromic anaemia. Similarly, progressive decrease in PCV was found following exposure of rats to lead $(\mathrm{Pb})$ acetate in a study conducted by Okediran, 2016. These haematological changes might be attributed to the toxic effect of lead on cell metabolism, interaction with some reactions where calcium is their secondary mediator, and inhibition of 
some enzymatic activities such as aminolevulinic acid dehydratase, which plays a key role in heme biosynthesis (Klaassen, 2011) and other erythrocyte enzymes, for example, GA3PD and G6PD. Continuous exposure to lead $(\mathrm{Pb})$ might adversely affect the heme biosynthesis in the body owing to the inhibition of cytoplasmic and mitochondrial enzymes. The depressing effects of lead $(\mathrm{Pb})$ acetate on the activity of major enzymes in the heme biosynthesis might be referred to imperfection of iron metabolism (Ejike, 2011). The inhibitory effect of lead $(\mathrm{Pb})$ acetate on conversion of coproporphyrinogen III to protoporphyrin IX results in shortening of erythrocyte life span and a decrease in the production of $\mathrm{Hb}$ which inturn result in reduction in the level of PCV (Jadwiga, 1994). The reduction of hematological values might be attributed to binding of lead to RBCs, which increase membrane fragility and destruction of RBCs (Oluwole, 2012). Administration of methanolic extract of Telfairia occidentalis in Group C which also receive lead however, showed improved levels of PCV compared to Group B which only receive lead $(\mathrm{Pb})$. The improved PCV level observed in Group $C$ can be attributed to the fact that Telfairia occidentalis contains iron, folic acid, vitamin $\mathrm{B}_{12}$ and protein which are active ingredient required for blood formation (Vreugdenhil et al., 1990).
Administration of lead $(\mathrm{Pb})$ to Group B shows increased level of white blood cells compared to all other experimental groups. This is in accordance with the study conducted by Farkhondeh et al., 2013 in which there was a significant increase in WBC in groups administered with lead $(\mathrm{Pb})$ acetate. The increase in WBC in Group B administered with lead $(\mathrm{Pb})$ can be attributed to induced inflammation (Inflammatory response caused by the lead $(\mathrm{Pb})$ and it's toxic actions on lymphoid organs which is agreement with the study of Sudakova in 2010.

\section{Conclusion}

Telfaria occidentalis administration ameliorates the deleterious histological testicular and epididymal changes, low plasma testosterone with concomitant low levels of packed cell volume. Telfaria occidentalis at a dose of 400 $\mathrm{mg} / \mathrm{kg}$ post-treatment attenuates the damaging effects of lead (Pb). It should therefore be included in the diet of individuals that are at high risk of exposure to endocrine disruptors and chemical agents like lead $(\mathrm{Pb})$ that are capable of inducing male infertility. The antioxidant potential of this wonder plant may have beneficial effects in treating male infertility

\section{REFERENCES}

1. Aiyelaagbe IO and Kintomo AA. 2002: Nitrogen Response of Fluted Pumpkin (Telfairia occidentalis Hook Grown Sole or Intercropped with Banana. Journal of Nutrient Cycling in Agroecosystems. 64(3):231-35.

2. Akang EN, Oremosu AA, Osinubi AA, Dosumu OO, Kusemiju TO, Adelakun SA, Umaru ML. 2015. Histomorphometric studies of the effects of Teilfairia occidentalis on alcohol induced gonadotoxicity in male rats. Toxicology reports 2: 968-975.

3. Akoroda MO. 1990. Ethnobotany of Telfairia occidentalis (Curcurbitacae) among Igbos of Nigeria. Journal of Economic Botany 44(1):29-39.

4. Badifu, Gabriel IO. 1993: Food Potentials of Some Unconventional Oilseeds Grown in Nigeria - a Brief Review. Journal of Plant Foods for Human Nutrition (43)3: 211-24.

5. Ejike CE and Ezeanyika LU 2011. Management of experimental benign prostatic hyperplasia in rats using a food based therapy containing Telfairia occidentalis seeds. Afr J Trad Complement and Altern Med. 8(4): 398-404.

6. Emebiri $L$ and Nwufo M. 1990. Pod Rots of Fluted Pumpkin (Telfairia Occidentalis Hook. F.) in Imo State, Nigeria. International Biodeterioration Journal (26)1: 63-68.

7. Eseyin OA, Ebong P, Ekpo A, Igboasoiyi A, Oforah E. 2007. Hypoglycemic effect of the seed extract of Telfairia occidentalis in Rat. Pak. J. Biol. Sci. 10(3): 498-501. 
8. Falana BA, Odundele OM, Duru FI, Osinubi AA, Falode DT. 2013. Molecular Characterization of Alkaline Phosphatase and PLAP in the Germinal Epithelium of $\mathrm{Pb}$ and $\mathrm{Se}+\mathrm{Zn}$ Treated Adult Sprague-Dawley Rats. Journal of Cell \& Developmental Biology; 2(3):14.

9. Farkhondeh T, Boskabady MH, Koohi MK, Sadeghi-Hashjin G, Moin M. 2013. The effect of lead exposure on selected blood inflammatory biomarkers in guinea pigs. Cardiovasc Hematol Disord Drug Targets. 13(1):45-9.

10. Giami SY. 2003: "Effect of Germination on Bread-Making Properties of Wheat-Fluted Pumpkin (Telfairia occidentalis) Seed Four Blends. Journal of Plant Foods for Human Nutrition 58(3):1-9.

11. Jadwiga C, Grazyna Z, Marzenna N. 1994. Combined effect of tin and lead on heme biosynthesis in rats. Ecotoxicology and Environmental Safety 29(2):165-73

12. Klaassen L, Sun Z, Steijaert MN, Bolte P, Fahrenfort I, et al. 2011. Synaptic transmission from horizontal cells to cones is impaired by loss of connexion hemichannels. PLoS Biol. 9(7):e1001107

13. Mohammadhosein Nm, Zahra H, Hiamidreza MS, Mohammad B. 2003. Effects of Chronic Lead Acetate Intoxication on Blood Indices of Male Adult Rat. Daru-Journal Of Faculty Of Pharmacy 11(4):147-151.

14. Nwanna EE, Oboh G. 2007. Antioxidant and Hepatoprotective Properties of polyphenol extracts from Telfairia occidentalis Leaves (Fluted Pumpkin) on acetaminophen induced liver damage. Pak J Biol Sci. 10(16):2682-7

15. Nwufo MI. 1994. Effects of Water Stress on the Post-harvest Quality of Two Leafy Vegetables, (Telfairia occidentalis) and - Storage Pterocarpus Soyauxii during Storage. J Sci Food Agric 64:265-69.

16. Okediran BS, Kasali OB, Omotainse SO and Akinloye OA. 2016. Haemato-Biochemical Alterations As Biomarkers of Lead Induced Toxicity in Male Wistar Rats. Bangl. J. Vet. Med. 14 (2): 227-232.

17. Okoli BE and Mgbeogu CM. 1983. Fluted Pumpkin, Telfairia occidentalis. West African Vegetable Crop. Econ Bot. 37(2):145-49.

18. Oluwole FS, Falade AO, Ogundipe OO. 2003. Anti-inflammatory effect of some common Nigeria vegetables. Nig J Physiol Sci; 18(1): 35-38.

19. Oyewopo A, Johnson O, Adeleke O, Oyewopo C. 2018. Review on the role of glutathione on oxidative stress and infertility. JBRA Assist. Reprod. 22 (1): 61-66.

20. Robertson S. 2015. Infertility Prevalence. News Medical Life Science. Available at: https://www.news-medical. net/health/Infertility-Prevalence.aspx. Accessed: 17/11/2017.

21. Shaban EM and El-Sayed Y. 2011. Influence of Vitamin C supplement on lead-induced histopathological alterations in male rats. Exp Toxicol Pathol. 63(3):221-7.

22. Vreugdenhil G, Wognum AW, van-Eijk HG, Swaak AJ. 1990. Anaemia in rheumatoid arthritis: the role of iron, vitamin B12, and folic acid deficiency, and erythropoietin responsiveness. Annals of the rheumatic diseases. 49(2):93-8

23. WHO - World Health Organization. 1991. Infertility: A tabulation of available data on prevalence of primary and secondary infertility. Programme on material and child health and family planning division of family health. Geneva: World Health Organization. 